\title{
Chinese agricultural technology transfer to African typical dry areas: practice and experience
}

\author{
Qiuxia MENG ${ }^{1,2}$, Jianjie ZHANG ${ }^{1,2}$, Wenyan XIE ${ }^{1,2}$, Huaiping ZHOU ${ }^{1,2}$, Qiang ZHANG (凶) ${ }^{3}$ \\ 1 College of Resources and Environment, Shanxi Agricultural University, Taiyuan 030031, China \\ 2 Institute of Agricultural Environment and Resources, Shanxi Academy of Agricultural Sciences, Taiyuan 030031, China \\ 3 Shanxi Agricultural University, Taiyuan 030031, China
}

\begin{abstract}
Africa has experienced increasing aridity and higher frequency of droughts due to climate change during the half past century with possible adverse effects on agricultural production, especially in dry areas with low rainfall. Under the auspices of the Africa Water Action Program between the Chinese Ministry of Science and Technology (MOST) and the United Nations Environment Program (UNEP), the Institute of Agricultural Environment and Resources, Shanxi Academy of Agricultural Sciences (SAAS-IAER) worked closely with domestic and overseas partners on technology transfer in Morocco, Zambia, Egypt, Niger and Ethiopia from 2008 to 2013. A drought early warning system has been established and validated, and drought adaptation technologies have been trialed, modified, demonstrated and extended in African countries, and this shows great potential to increase crop production, water and fertilizer use efficiency and desert control in rainfed areas of Africa. The project has continued for six years and is a successful case of technology transfer and capacity building in Africa. The knowledge and experience gained will be useful to researchers, technicians, aid agencies and policy makers who work on agricultural technology transfer for in dry areas of Africa.
\end{abstract}

Keywords drought, early warning, adaptation technology, China, United Nations Environment Program, Africa

\section{Introduction}

Droughts over the past half century have been characterized by higher frequency, earlier onset and longer duration as a result of climate change ${ }^{[1-4]}$. Prolonged and frequent

Received November 15, 2019; accepted June 5, 2020

Correspondence: sxsnkytfs@163.com drought events are profoundly affecting the agricultural production and livelihood of many people worldwide, particularly those who live in dry areas with low rainfall. This also represents an environmental threat leading to desertification, salinity, soil and water erosion, water pollution and increased sedimentation of reservoirs. Water shortage has become a factor limiting the agricultural, economic and social development of many countries. In recent decades, global warming has forced many countries to address and adapt to the impacts of climate change. Developed countries are less vulnerable to climate change due to their capacity to adapt and mitigate, while developing countries, including many African countries, are the most affected. IPCC (2007) predicted that Africa would be most adversely affected by climate change ${ }^{[5]}$. In fact, climate change has been exerting a negative impact on crop production in Africa ${ }^{[6]}$. It is estimated by IPCC that climate change will reduce yields from rainfed agriculture by up to $50 \%$ in some Africa countries in $2020^{[7]}$.

More than $70 \%$ of African countries and areas are facing the issue of water scarcity, and 300 million people remain in poverty because of water scarcity ${ }^{[8]}$. Droughts and desertification are aggravating in Africa with the intensification of global warming. Lake Chad, for instance, has shrunk by half in area in the past 50 years ${ }^{[9]}$. More than $75 \%$ of agricultural land in Africa is rainfed ${ }^{[10]}$, which is highly vulnerable to droughts. Long drought events in Morocco from 1980 to 1985 and 1990 to 1995 forced the country to double the amount of cereals imported in 2001 in the aftermath of the preceding dry years ${ }^{[11]}$. A drought in north Africa struck Morocco hardest in 2007, leading to a $75 \%$ decline in wheat production compared to $2006^{[12]}$. In future decades, 500 million people in Africa will have to face the challenge of water scarcity, and all the countries are projected to see 3\%-30\% decreases in food production due to water shortages ${ }^{[13,14]}$. Developed science and technology on water management and utilization are critical approaches in tackling the pressing water crisis, 
ensuring water and food security and promoting sustainable development.

Agricultural drought represents a major threat to food security. Ecological modeling for early prediction and monitoring of drought is a powerful tool for timely response and mitigation of adverse effects to the maximum extent, for example by adjusting planting conditions (e.g., crop variety, date of sowing, seeding rate, and fertilization regime) as the seasonal rainfall information is issued. Scenario simulation is an important way of tracing nutrient dynamics and optimizing management practices in an ecosystem. From the temporal and spatial perspectives, however, relying solely on historical data results in a certain delay in management policy research. In particular, more errors will occur in the simulated results due to ecosystem factors that fluctuate frequently with time and thus increase the uncertainty of the whole system. The establishment of a drought early warning system (DEWS) by developing software tools for dynamic predictions of drought impacts on yields over large geographical regions can provide valuable information for government and public decision makers.

The Chinese strategic objective is to increase Africa's own food supply by participating and helping in African agricultural development but not to meet China's food demand by large-scale plantation in Africa. China has been providing support for African agricultural development since $1996^{[15]}$. For seven decades, drought mitigation technology systems for different Chinese climate types were developed including farmland moisture monitoring, drought prediction, and water conservation farming. A number of institutions cooperated with African countries and made substantial progress. In the first decade of the 21 st century, the Institute of Agricultural Environment and Resources, Shanxi Academy of Agricultural Sciences (SAAS-IAER, formerly the Institute of Soils and Fertilizers, SAAS) extended drought adaptation technology to Morocco and Libya, and the Yangling Agricultural Hightechnology Industries Demonstration Zone conducted demonstrations on cultivation of drought-resistant highyielding wheat in Egypt and Sudan. Scientific and technological aid, cooperative research, technology demonstration and transfer of Chinese drought mitigation technology benefit capacity building, water and food security, and environmental safety of African countries, and to the export of Chinese agricultural technology, products, equipment and standards. More intensive and extensive cooperation in science and technology between China and Africa is also helpful in mutual understanding and friendship of peoples from both lands. Chinese technological cooperation with Africa on water resources therefore needs overall planning, proactive deployment and synergistic advancement to overcome problems such as limited sponsorship, small project scale and lack of sustainability.

\section{African agriculture}

Agriculture dominates the economies of most African countries, contributes more than $20 \%$ of the GDP and employs $61 \%$ of the total population in the continent ${ }^{[16]}$. Africa is an important area of tropical and sub-tropical crop production of global significance. The export of agricultural products, mainly tropical and sub-tropical cash crops, accounts for a quarter of the gross exports. In fact, despite the favorable conditions for production of domestic agricultural crops, many countries have committed their material, human, and financial resources to the production of cash crops for export. Large commercial farms equipped with modern farming facilities and subsistence farms or small-family mixed farms that have poor land and limited production resources are therefore commonly found coexisting in many African countries (Fig. 1). In addition, shifting cultivation is still prevalent in many countries. The crop yields of smallholder farms and shifting cultivation are low and highly variable depending on the climate. Even in good harvest years, north African countries rely heavily on cereal imports from the international market to cover their needs, and $63 \%$ on average of the domestic cereal requirement is met through imports ${ }^{[17]}$. Most sub-Saharan countries require external assistance for food due to irregular rains and extended dry spells or civil unrest ${ }^{[17]}$. There is still a long way to combat food shortages. Hence, it is very important to support smallholder agriculture through technology transfer and capacity building in many rural areas, thereby promoting greater productivity and greater recovery of production and sustainability of farming incomes when it comes to African food security and agricultural development.

Water shortage greatly restrains agricultural development in Africa. Precipitation is uneven in terms of spatial distribution. Areas near the equator receive the largest amount of rainfall in the world, and this declines increasing latitude north and south. Half of the continent receives less than $500 \mathrm{~mm}$ of annual precipitation. The northern Sahara and the south-west of Africa constitute $40 \%$ of the entire dry area of the continent with annual precipitation below $250 \mathrm{~mm}^{[18]}$. Central Africa and the northern part of west Africa face hunger and famine caused by poor harvests resulting from very severe droughts. Diversity of land holding systems adds to the complexity of the situation. Furthermore, demographic pressures and anthropogenic activities exacerbate the effects of climate change due to a lack of institutional and technological solutions. With temperatures predicted to rise by $2-3^{\circ} \mathrm{C}$ by 2050 and rainfall to decline by $10 \%-20 \%$ under the SRES A1B scenario $^{[19]}$, government and farmers face a massive challenge to mitigate the impacts of climate change, especially more severe and frequent droughts. Although adaptation strategies that are regarded as "traditional" such as shifting planting patterns, traditional irrigation and 

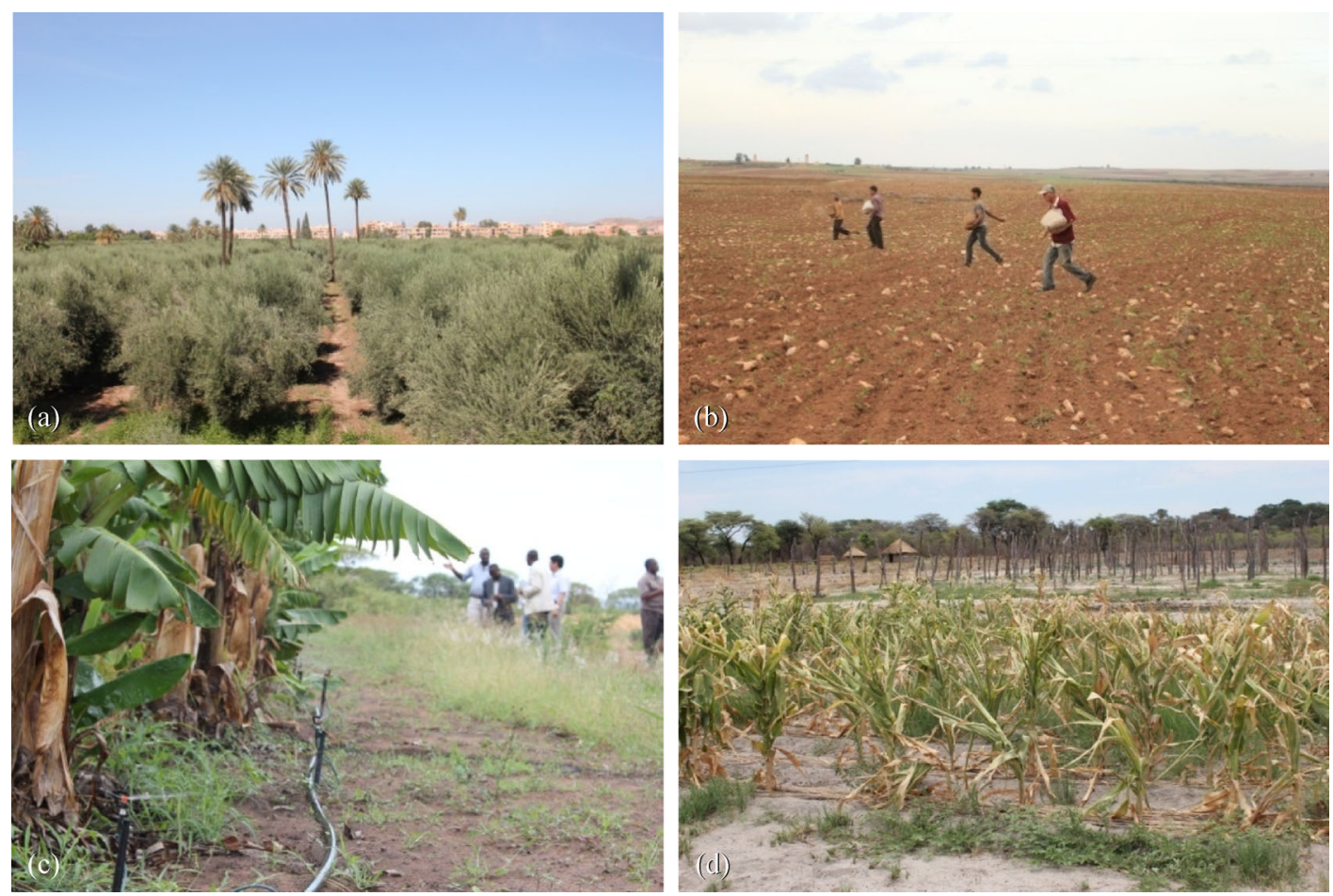

Fig. 1 The coexistence of large commercial farms and subsistence farms or small-family mixed farms in Africa. (a) A commercial olive plantation in Marrakesh, Morocco (November 3, 2012; 11:48 A.M.); (b) sowing barley (that needs less water and ripen faster than wheat) by hand on Abda Plain, Morocco (November 6, 2012; 4:50 P.M.); (c) a large commercial farm equipped with modern farm machinery in Southern Province, Zambia (November 19, 2012; 10:54 A.M.); (d) harvest failure of maize caused by drought in a smallholder farm in Southern Province, Zambia (November 19, 2012; 12:06 P.M.)

planting after late rains have evolved and been used in Africa over hundreds of years. Increasing population pressure and the necessities of the African economy make it inevitable to invite modern adaptation strategies to overcome biophysical constraints to dryland agriculture resulting from acute water scarcity, frequent droughts, desertification and other forms of land degradation.

\section{Africa Water Action: a China-UNEP-Africa cooperative environment program}

A memorandum of cooperation was initialed between the Chinese Ministry of Science and Technology (MOST) and the United Nations Environment Program (UNEP) in November 2007. It confirmed that both parties would provide capacity building and technical support to African countries in environment-related areas including disaster alleviation and climate adaptation, sustainable use of energy, information exchange on energy saving and emission reduction, biodiversity conservation, and other areas related to environmental protection and improvement. The Africa Environmental Technology and Institutional Cooperation and Exchange Framework memorandum of understanding was formally signed between MOST and UNEP one year later.
The Africa Water Action, the China-UNEP-Africa Cooperation Program on the Environment, funded by MOST, was jointly initiated by UNEP and MOST in 2008. All projects were identified based on the UNEP Program of Work (PoW) and the needs of the African countries. The main objective was oriented toward enhancing African capacities to address environmental challenges facing the continent through experience exchange, technical transfer and information sharing with the Chinese scientists. Objectives of the projects were accomplished through training workshops, a visiting scholar program and demonstration pilot projects. The projects were funded by MOST and jointly implemented by more than 20 Chinese and African universities, academic institutions and organizations under the overall coordination of the Regional Office for Africa (ROA) at UNEP. The projects of the Africa Water Action have been conducted in two phases as listed in Table 1.

Within this framework, SAAS-IAER was commissioned by the Department of International Cooperation, MOST, to undertake a fourth project titled "Cooperation in drought early warning systems and adaption technology in the drought regions of Africa" in phases I and II consecutively. SAAS-IAER and other domestic participants, Lanzhou University, Gansu Desert Control Research Institute, Northwest A\&F University and Space Star Technology 
Table 1 Projects in the two phases of the Africa Water Action Program

\begin{tabular}{|c|c|c|c|}
\hline Phase & Aims & Projects & African countries involved \\
\hline $\begin{array}{l}\text { Phase I } \\
(2008-2010)\end{array}$ & $\begin{array}{l}\text { To build the capacity of African } \\
\text { countries in ecosystem management, } \\
\text { disaster reduction, climate change } \\
\text { adaptation and renewable energy }\end{array}$ & $\begin{array}{l}\text { (1) Re-use of wastewater for forest plantation } \\
\text { (2) Training and technical support on rainwater harvesting } \\
\text { in Africa } \\
\text { (3) Enhancing the capacity of monitoring shared water } \\
\text { resources of Lake Tanganyika } \\
\text { (4) Drought early warning systems and adaptation to } \\
\text { drought }\end{array}$ & $\begin{array}{l}\text { Burundi, D. R. Congo, Egypt, Kenya, } \\
\text { Libya, Morocco, Mozambique, Rwanda, } \\
\text { South Africa, Tanzania, and Zambia }\end{array}$ \\
\hline $\begin{array}{l}\text { Phase II } \\
\text { (2011-2013) }\end{array}$ & $\begin{array}{l}\text { To strengthen African capacity for } \\
\text { sustainable management of limited } \\
\text { water resources with ecosystem } \\
\text { approach under the theme "One } \\
\text { River, One Lake, and One Desert", } \\
\text { targeting the River Nile, Lake } \\
\text { Tanganyika and the Sahara desert }\end{array}$ & $\begin{array}{l}\text { (1) Water resources planning for selected water catchments } \\
\text { in Africa } \\
\text { (2) Development and demonstration of new technologies } \\
\text { for safe water supply } \\
\text { (3) Water quality and ecosystem monitoring and } \\
\text { demonstration of new wastewater treatments } \\
\text { (4) Drought early warning system and adaption technologies } \\
\text { for the dry areas of Africa } \\
\text { (5) Development and demonstration of water-saving } \\
\text { techniques for dryland agriculture and agricultural mapping } \\
\text { in Africa } \\
\text { (6) Development and demonstration of technologies for } \\
\text { combating desertification }\end{array}$ & $\begin{array}{l}\text { Algeria, Burundi, Egypt, Ethiopia, } \\
\text { Kenya, Mauritania, Mali, Morocco, } \\
\text { Nigeria, Niger, Sudan, Tanzania, } \\
\text { Uganda, Zambia, and Zimbabwe }\end{array}$ \\
\hline
\end{tabular}

Co., Ltd., worked hand-in-glove with their African counterparts.

\section{Aims of the project}

The project "Cooperation on drought early warning system and adaption technology in the drought regions of Africa" aimed to: (1) establish drought early warning systems for typical regions of Africa and thus to enhance the drought prediction and early warning capabilities of African countries; (2) integrate the drought mitigation technologies well developed in China and establish demonstration sites for dryland farming technology in typical regions of Africa and thus improve the drought-resistance capability of crops and cushion the losses caused by drought in Africa; (3) provide training to technical staff and organize personnel communication and exchange and thus to promote capacity building of African researchers and technicians; and (4) enhance theoretical research capacity and technology adaptability in agroclimatic, hydrological, modeling and other related areas (drought and climate change). Eventually, mutual understanding and friendship between Chinese and African people and capacity building on drought early warning systems and adaption technology in the dry regions of Africa would be promoted.

\section{Project implementation and outcomes}

The project was conducted mainly in Morocco, Zambia, Ethiopia, Niger, and Egypt. As shown in Fig. 2, each of the four Chinese research institutions/universities was paired with one or two African country/countries based on the their research strengths and the African countries' actual situation. Space Star Technology Co., Ltd. provided the data and technical support required. Cooperation agreements and memoranda of understanding were signed between the Chinese and African partners, respectively. The researchers from China and Africa worked closely in field investigation and survey to identify the gaps between the current drought prediction/drought mitigation technologies and the actual demands in the African countries studied, and then established DEWS, introduced welldeveloped Chinese drought adaptation technologies to the African countries via the establishment of demonstration sites, developed water-conservation farming patterns adapted to Africa by rational integration and field trials of various drought mitigation technologies, and promoted capacity building by technical training and personnel exchange. Scaled-up application followed in terms of extension spots/farms, technical training and media publicity.

\subsection{Field investigations and surveys}

Understanding the climate, soil, actual farming systems and components, farmers' capability to invest in crop subsystems, and farmers' strategies to adapt to climate change, is necessary the identification of the transferable drought adaptation technologies to the project area. As a result, more than ten missions were organized to identify the actual technology demands and transferrable technologies to the cooperating African countries. These missions comprised researchers from China and their corresponding African partners, and they conducted investigations on climate, soil, desertification, farming system and the drought mitigation technologies in use with field 


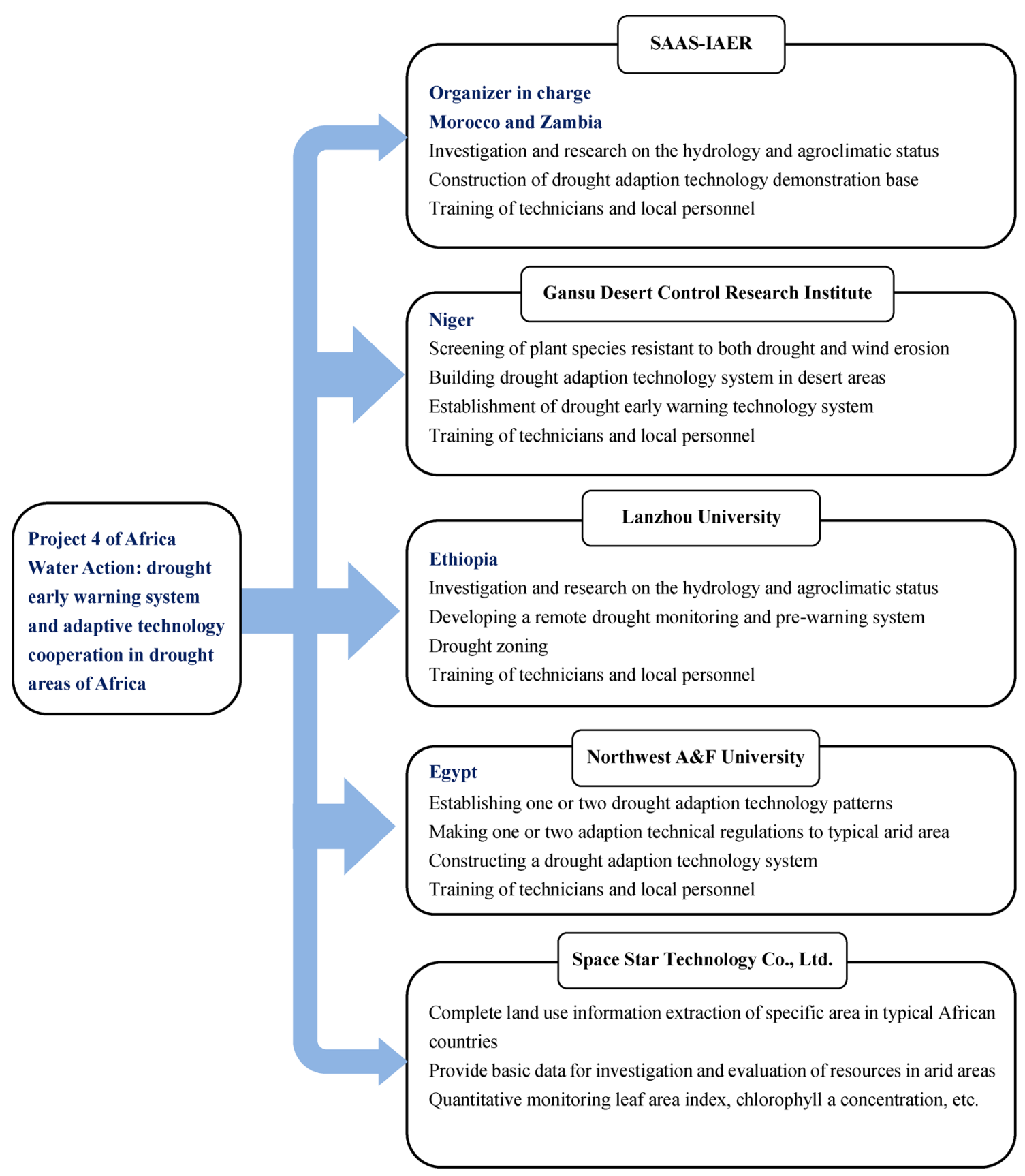

Fig. 2 Implementation chart of the project.

observations, questionnaire surveys and interviews with local farmers and technicians (Fig.3). Documents and academic reports were also referred to. The results of the investigation and surveys were summarized in a series of reports written by the project members. Field investigation and surveys helped the project members to understand the actual situation of African agriculture and also provided opportunities for direct communication with local farmers, technicians and agricultural administrative officials and acquisition of valuable first-hand information. The information collected was incorporated with the Analytic
Hierarchy Process (AHP) method in the selection of drought adaptation technologies transferred to African countries.

\subsection{Drought zoning and land use planning}

Drought zoning of Ethiopia was accomplished by researchers from Lanzhou University. The eventual aim of Ethiopian agricultural drought zoning was to use and develop land in an effective, rational and scientific manner based on information on the current land use situation, 

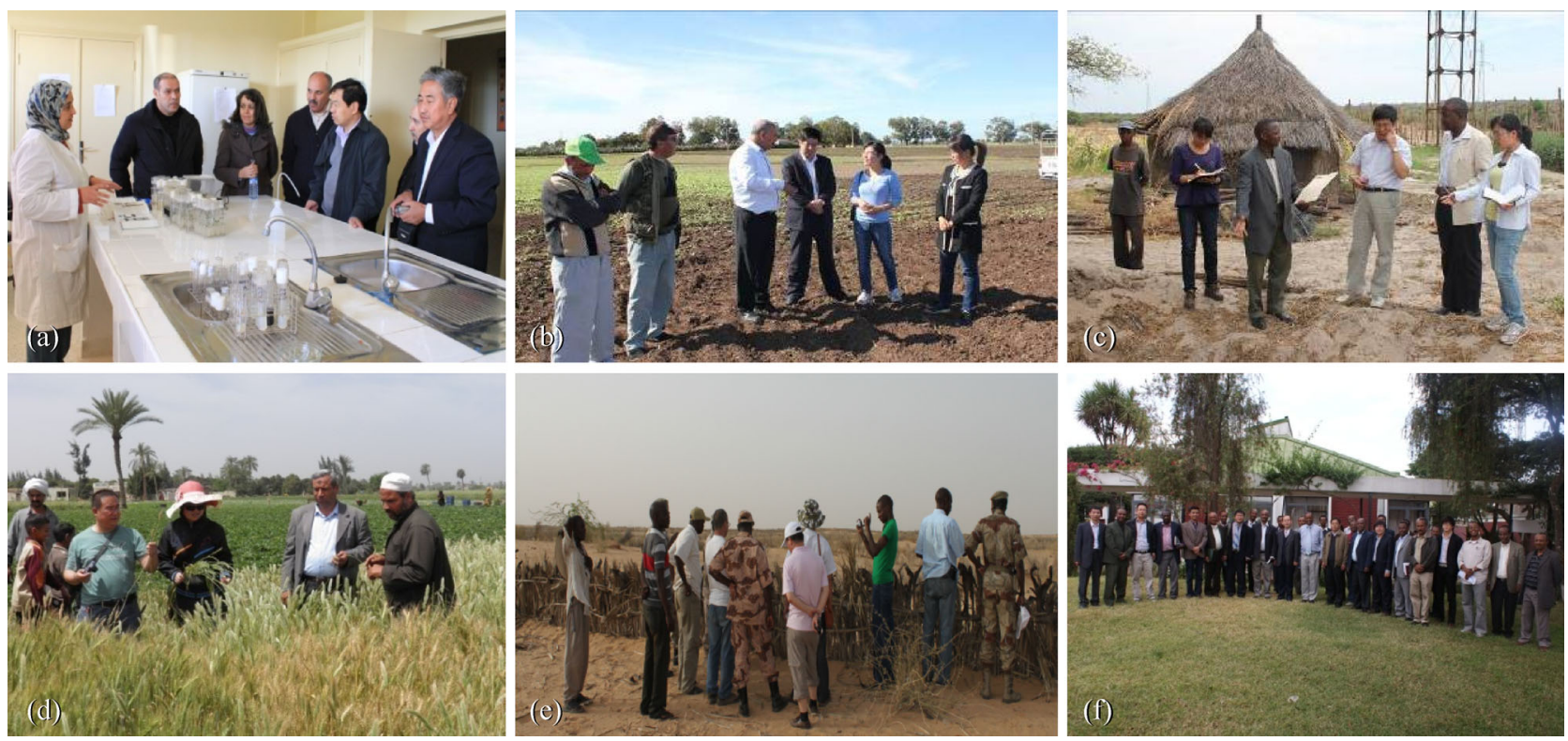

Fig. 3 Field investigations and surveys in differrent African countries conducted by joint China-Africa missions. (a) Field invesigation in Kennitra, Morocco (November 23, 2011; 11:57 A.M.); (b) farming system survey in Safi, Morocco (November 14, 2012; 11:25 A.M.); (c) farming system survey in Southern Province, Zambia (November 19, 2012; 11:57 A.M.); (d) farming system survey in Ismailia and Suez, Egypt (CYongzhong Feng \& Youzhen Xiang, November 14, 2012; 11:09 A.M.); (e) vegetation and farming system survey in Zinder, Niger (CFaming Li, June 6, 2012; 17:42 P.M.); (f) field investigation in Ethiopia (CFeng Zhang, November 25, 2011; 16:01 P.M).

usable resources, ecology and environment and socioeconomic conditions acquired during the investigation. The causes and current situation of desertification in Niger were studied by researchers from Gansu Desert Control Research Institute to provide a scientific basis for desert control, environmental protection and the sustainable development of the economy. The implementation of these tasks is summarized in Table 2.

\subsection{Construction of drought early warning system}

The mobile versions of drought early warning software based on iPhone and iPad, tailored for African countries, were released in the project. The website versions of the drought early warning system and the drought early warning data integration platform were also finalized. The sensor data acquisition platform was preliminarily

Table 2 Drought zoning and land use planning in the project

\begin{tabular}{|c|c|c|c|c|}
\hline Key technology & Partners & Key achievements & Main constraints & Recommendations \\
\hline $\begin{array}{l}\text { Drought zoning of } \\
\text { Ethiopia }\end{array}$ & $\begin{array}{l}\text { Lanzhou University. } \\
\text { Ethiopian Institute of } \\
\text { Biodiversity. Ethiopian } \\
\text { Institute of Agricultural } \\
\text { Research }\end{array}$ & $\begin{array}{l}\text { Agricultural drought sensitivity } \\
\text { evaluation and zoning of Ethiopia. } \\
\text { Comprehensive drought risk } \\
\text { evaluation and zoning of Ethiopia. } \\
\text { Corresponding countermeasures } \\
\text { based on the zoning, including } \\
\text { rational irrigation, adjustment of } \\
\text { cultivation structure, hydraulic } \\
\text { engineering, enhancement of the } \\
\text { agricultural environment, and } \\
\text { establishment of DEWS }\end{array}$ & $\begin{array}{l}\text { Lack of environmental } \\
\text { consciousness in farmers. } \\
\text { Difficulty in data collection }\end{array}$ & $\begin{array}{l}\text { Continuing education provided by } \\
\text { local communities, governments } \\
\text { and international organizations. } \\
\text { Arrange more human resources and } \\
\text { funding for field surveys and other } \\
\text { data collection activities }\end{array}$ \\
\hline $\begin{array}{l}\text { Desertification } \\
\text { classification of Niger }\end{array}$ & $\begin{array}{l}\text { Gansu Desert Control } \\
\text { Research Institute. } \\
\text { Ministry of environment } \\
\text { and water resources, } \\
\text { Niger }\end{array}$ & $\begin{array}{l}\text { A desertification classification } \\
\text { map of Niger based on the } \\
\text { MODIS13Q1-NDVI. } \\
\text { A sustainable agricultural } \\
\text { development planning for Niger. } \\
\text { Different developing measures } \\
\text { for each land category }\end{array}$ & $\begin{array}{l}\text { Lack of environmental } \\
\text { consciousness in farmers. } \\
\text { Low inputs in agriculture } \\
\text { and overexploitation of land. } \\
\text { Difficulty in data collection }\end{array}$ & $\begin{array}{l}\text { Continuing education provided by } \\
\text { local communities, governments } \\
\text { and international organizations. } \\
\text { Help farmers to access chemical } \\
\text { fertilizers, certified seeds and irri- } \\
\text { gation facilities. } \\
\text { Arrange more human resources and } \\
\text { funding for data collection }\end{array}$ \\
\hline
\end{tabular}


established and the agriculture production models for Ethiopia, Zambia, Morocco, and Niger preliminarily constructed. The drought early warning system was preliminarily extended and showcased in Morocco and Ethiopia, and the software was verified using actual measured data when the project closed. The DEWS serves two types of clients, i.e., mobile clients and web service clients. It uses a four-tiered architecture (Fig. 4). (1) An ecological monitoring and data collection system supported by a local GIS-based database and ecological sensor data; (2) a database integration system which can assimilate multi-source data for the simulation system; (3) an ecosystem process simulation system; and (4) an information distribution system which may be accessed through personal computers and mobile devices such as smart phones and tablets.

\subsection{Technology demonstration, field trials and extension}

With the joint efforts of the Chinese and African participants, demonstration sites of drought adaptation technology were established and field trials arranged in Morocco, Zambia, Egypt and Niger from 2011 to 2013. Settat Agricultural Research Center and Kenitra Agricultural Research Center, National Institute of Agronomic Research of Morocco (INRA, Morocco), Zambia Meteorological Department; the College of Agricultural Sciences of the University of Zambia; Suez Canal University of Egypt and the Ministry of Environment and Water Resources of Niger played important roles in the trials. The efforts made by the African partners were essential for the success of the technology demonstration and field trials because most of them were highly cooperative and informative. Local technicians and farmers showed great interest in the demonstrations and field trials, and participated the hand-on training with great enthusiasm (Fig. 5). Upon the completion of the experimentation and demonstration, researchers from universities and research institutions agreed to conduct further studies to adapt the technologies to the local production situation. In addition to the hand-on training, English copies of the operating specifications of the drought adaptation technologies were prepared and distributed to the African partners to ensure continuing application. The tested, demonstrated and extended drought adaptation technologies are listed in Table 3.

\subsection{Intellectual property}

From the project, eight academic papers were published in international journals such as The Scientific World Journal and domestic journals including World Agriculture and Journal of Desert Research. A total of two books were published and 10 reports completed. Two textbooks were issued during the training sessions. Furthermore, one practical technical manual for drought mitigation technology, two technical regulations on dryland drought adaptation technology were issue and four software copyrights on DEWS and drought adaptation technology were granted. Table 4 summarizes the intellectual property obtained in the project apart from published articles. These works provide valuable information and references for DEWS development, drought mitigation and technology transfer in the future.

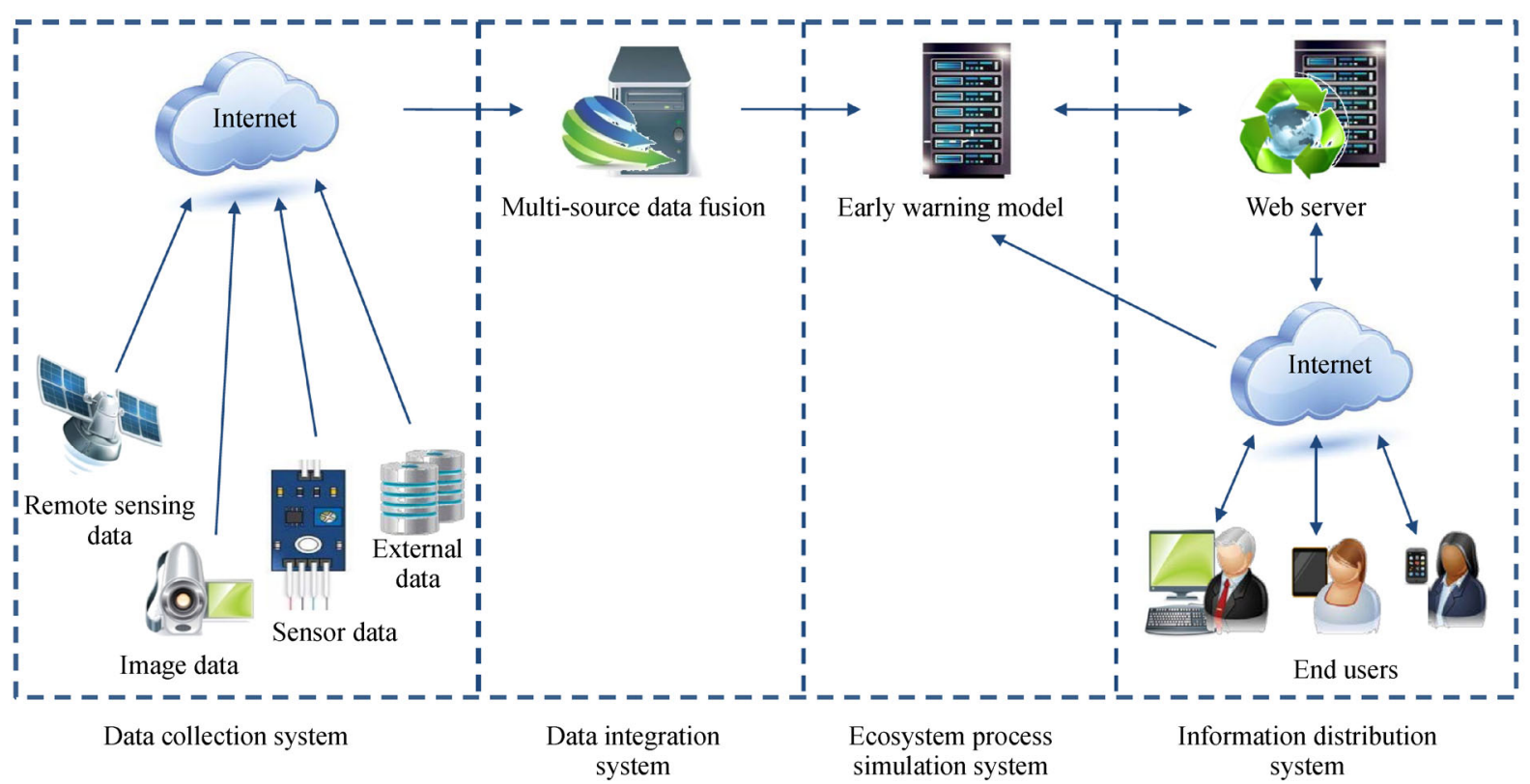

Fig. 4 The architecture of the drought early warning system (DEWS). 

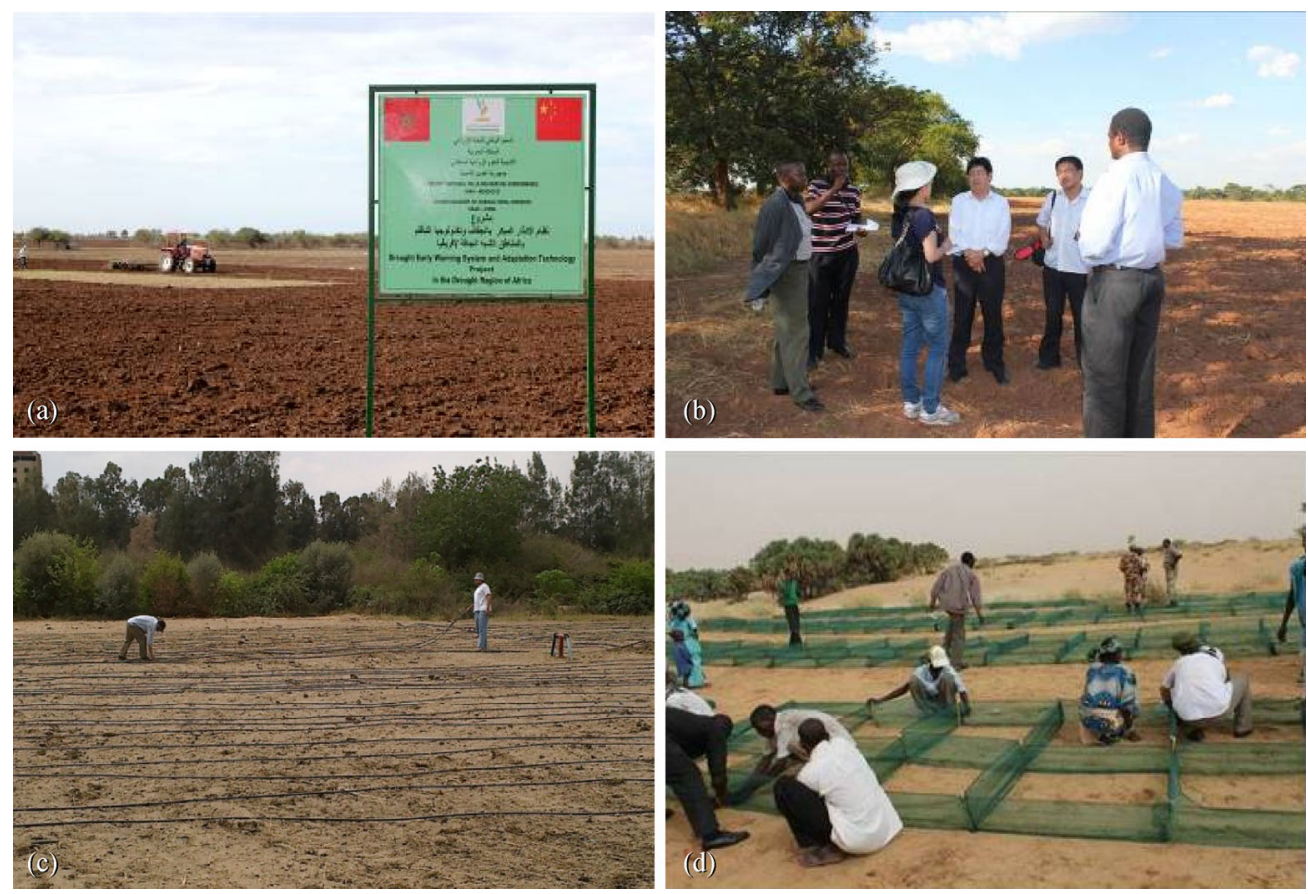

Fig. 5 Demonstration sites in (a) Morocco (November 6, 2012; 11:46 A.M.), (b) Zambia (November 20, 2012; 16:21 P.M.), (c) Egypt (CYongzhong Feng \& Youzhen Xiang, May 28, 2012; 16:23 P.M.), and (d) Niger (CFaming Li, June 10, 2012; 16:21 P.M.).

Table 3 Demonstrations, field trials and extension of drought adaptation technology in different African countries

\begin{tabular}{|c|c|c|c|c|}
\hline Key technology & Location/coverage & Key achievements & Main constraints & Recommendations \\
\hline $\begin{array}{l}\text { Zinc-manganese } \\
\text { balanced fertilization } \\
\text { of soft wheat }\end{array}$ & $\begin{array}{l}\text { Safi, Morocco } \\
1200 \mathrm{~m}^{2}\end{array}$ & $\begin{array}{l}\mathrm{Zn} \text { application resulted in a grain } \\
\text { yield of } 1028 \mathrm{~kg} \cdot \mathrm{ha}^{-1} \text {, an increase } \\
\text { of } 29 \% \text { over the control. } \\
\text { Mn application induced an increase } \\
\text { of } 27 \% \text { over the control }\end{array}$ & $\begin{array}{l}\text { Increased investment costs for } \\
\text { fertilizers. } \\
\text { Zinc and manganese fertilizers } \\
\text { are not available locally }\end{array}$ & $\begin{array}{l}\text { Combine with DEWS and use in the } \\
\text { wet years. } \\
\text { Help in access to fertilizers }\end{array}$ \\
\hline $\begin{array}{l}\text { Zinc-manganese } \\
\text { balanced fertilization } \\
\text { of lentil }\end{array}$ & $\begin{array}{l}\text { Safi, Morocco } \\
1200 \mathrm{~m}^{2}\end{array}$ & $\begin{array}{l}\text { The grain yield increases were } 28 \% \\
\text { for zinc, } 30 \% \text { for manganese and } \\
7 \% \text { for combined fertilization, and } \\
\text { reached } 615,626 \text { and } 518 \mathrm{~kg} \cdot \mathrm{ha}^{-1} \text {, } \\
\text { respectively, despite climate } \\
\text { constraints }\end{array}$ & As above & As above \\
\hline $\begin{array}{l}\text { Zero-tillage, straw } \\
\text { mulching and nitrogen } \\
\text { management of soft } \\
\text { wheat }\end{array}$ & $\begin{array}{l}\text { Safi, Morocco } \\
1200 \mathrm{~m}^{2}\end{array}$ & $\begin{array}{l}\text { Straw-mulching increased grain } \\
\text { yield by } 34 \% \text { and reached } \\
1775 \mathrm{~kg} \cdot \mathrm{ha}^{-1} \text { compared to } \\
1326 \mathrm{~kg} \cdot \mathrm{ha}^{-1} \text { in non-mulched } \\
\text { control when two droughts struck } \\
\text { during the growth period. } \\
\text { Nitrogen input }\left(60 \mathrm{~kg} \cdot \mathrm{ha}^{-1}\right) \\
\text { increased grain yield by } 12 \% \\
\text { in the very dry year of } 2012\end{array}$ & $\begin{array}{l}\text { Increased investment costs for } \\
\text { straw and labor } \\
\text { The use of crop residues for } \\
\text { other purposes (i.e., fuel or } \\
\text { livestock feed) }\end{array}$ & $\begin{array}{l}\text { Subsidies provided by local } \\
\text { government and community }\end{array}$ \\
\hline $\begin{array}{l}\text { Zero-tillage, straw } \\
\text { mulching and nitrogen } \\
\text { management of lentil }\end{array}$ & $\begin{array}{l}\text { Safi, Morocco } \\
1200 \mathrm{~m}^{2}\end{array}$ & $\begin{array}{l}\text { No-tillage, and previous cereal } \\
\text { fertilizer-N rate of } 60 \mathrm{~kg} \cdot \mathrm{ha}^{-1} \\
\text { resulted in grain yields of } 467 \\
\text { and } 463 \mathrm{~kg} \cdot \mathrm{ha}^{-1} \text {, increases of } 20 \% \\
\text { and } 11 \%, \text { respectively }\end{array}$ & As above & As above \\
\hline $\begin{array}{l}\text { Drought-resistant seed } \\
\text { coating agent on soft } \\
\text { wheat }\end{array}$ & $\begin{array}{l}\text { Safi, Morocco } \\
1200 \mathrm{~m}^{2}\end{array}$ & $\begin{array}{l}\text { Foliar spraying with fulvic acid } \\
\text { increased grain production to } \\
1743 \mathrm{~kg} \cdot \mathrm{ha}^{-1} \text { but not } \\
\text { significantly }\end{array}$ & $\begin{array}{l}\text { Unwillingness of farmers to } \\
\text { invest more due to yield } \\
\text { uncertainty in the very dry } \\
\text { years }\end{array}$ & $\begin{array}{l}\text { Combine with other methods such as } \\
\text { altering sowing date and choose } \\
\text { drought-resistant cultivars }\end{array}$ \\
\hline
\end{tabular}




\begin{tabular}{ll}
\hline Key technology & Location/coverag \\
\hline $\begin{array}{l}\text { Drought-resistant seed } \\
\text { coating agent on soft } \\
\text { wheat }\end{array}$ & $\begin{array}{l}\text { Safi, Morocco } \\
1200 \mathrm{~m}^{2}\end{array}$ \\
& \\
$\begin{array}{l}\text { On-farm technology } \\
\text { transfer on wheat and }\end{array}$ & $\begin{array}{l}\text { Six private farms } \\
\text { in Abda area } \\
\text { lentil }\end{array}$ \\
\end{tabular}

Zinc-boron balanced fertilization

Duel-mulching with plastic film and straw

Drip-irrigated film- or straw- mulched furrow and ridge planting technology

Nylon net sand-break and traditional sand fixation techniques

Rain collection using fish scale-shaped pits for forestation

Chinese millet cultivation method

Alternate large and small ridges with or without plastic film mulching

Selection of soil and water-conserving plants
Liempe, Zambia $600 \mathrm{~m}^{2}$

Liempe, Zambia $600 \mathrm{~m}^{2}$

Ismailia, Egypt $3000 \mathrm{~m}^{2}$

Grouré, Niger $1000 \mathrm{~m}^{2}$

Dosso, Niger $800 \mathrm{~m}^{2}$

Tahoua, Niger $800 \mathrm{~m}^{2}$

Tahoua, Niger $800 \mathrm{~m}^{2}$

Increase maize yield effectively by $56 \%$

Niamey, Niger

Selected 12 local economic tree species and more than 10 windbreak and sand-fixing plant species with economic value above ground biomass, grain yield or harvest index showed good effect.

Farmers and technicians were very interested and active

Effectively increase the survival rate of tree seedlings by $75 \%$
Demand a special drill machine for direct seeding that is costly to farmers and not available in

Develop/introduce low-cost and were compared to conventional farming practice. No-till package increased grain yield the local markets. of soft wheat and lentil by $8.8 \%$ and Labor scarcity and high costs of $20.4 \%$, respectively. Very informative to the farmers and they are in the process of adapting

weeding and harvesting

Affected by soil dilution and by Use in the form of a foliar spray. weather limitations.

Increased investment cost

The use of crop residues for other purposes (i.e., fuel or livestock feed).

Unwillingness of farmers to invest more due to yield uncertainty while costs are increased.

No fencing to avoid grazing

by roaming animals

Initial investment costs are high. Modify by replacing drip-irrigation Too complicated for local farmers.

Lack of auxiliary facility

Nylon net is not available locally

Use local materials such as bush branches

Low incentives due to lack of immediate returns

Provide subsidies by local government and community

Inadequate awareness of local people toward intensive farming.

Conservative attitude of locals to Chinese millet species

Difficulty in mastering the technology by local farmers. Environmental concern about pollution by plastic film residues

Emphasize the role of local technicians in continuing technology extension and services.

Transfer the technology to local millet species

Emphasize the role of local technicians in continuing technology extension and services.

Introduce bio-degradable film or thicker film that can be collected easily after harvest

Lack of product processing infra- Increase infrastructure input, structure and technology. technical training and subsidies Low incentives due to lack of by local government and markets and immediate returns community.

Cooperate with international companies in product value chain development 
Table 4 Selected intellectual property produced by the project

\begin{tabular}{|c|c|}
\hline Type & Title \\
\hline \multirow[t]{10}{*}{ Report } & A Report on Drought Zoning of Ethiopia \\
\hline & Investigation on Farming Systems in the Dry Areas of Morocco \\
\hline & Drought Management in the Dry Area of Morocco \\
\hline & Drought early Warning System (DEWS) and Drought Mitigation Techniques Research in Morocco \\
\hline & Status of Drought Early Warning System and Drought Mitigation Techniques Research in Zambia \\
\hline & Annual report on field trials of drought adaptation technologies in Morocco $(2012,2013)$ \\
\hline & An Investigative Report on Characteristics of Egyptian Farming Systems in the Nile Delta \\
\hline & A Report on Egypt's Current Food Security Situation and Projected Food Supply Capacity \\
\hline & Annual Report on Field Trials of Drought Adaptation Technologies in Egypt \\
\hline & Desertification Monitoring Study and Background Survey on Vegetation in Typical regions of Niger \\
\hline \multirow[t]{2}{*}{ Book } & An investigative report on characteristics of farming systems in Egypt (China Agriculture Press, 2014) \\
\hline & Eco-industry Construction of Hexi Corridor (Gansu Science and Technology Press, 2013) \\
\hline \multirow[t]{2}{*}{ Textbook } & A Training Manual on Desertification Prevention and Control Technology \\
\hline & The construction and development of facility agriculture in arid areas \\
\hline Technical Manual & Practical technical manual for drought mitigation technology (UNEP and MOST, 2014) \\
\hline \multirow[t]{5}{*}{ Training manual } & Agricultural drought mitigation technology using chemicals \\
\hline & Straw-mulching and zero-tillage technology \\
\hline & Balanced fertilization technology \\
\hline & Film-mulched alternate large and small ridges and furrow sowing technology for maize \\
\hline & Drip-irrigated film-mulched furrow and ridge cultivation of maize \\
\hline \multirow[t]{4}{*}{ Software copyright } & Agricultural decision supporting system based on GIS V1.0.0.0 (Reg. No. 2012SR124525) \\
\hline & Data sharing system (Reg. No. 2012SR078098) \\
\hline & Project management system (Reg. No. 2012SR124749) \\
\hline & Intelligent crop management system V 1.0 (Reg. No. 2013SR071106) \\
\hline
\end{tabular}

\subsection{Personnel training}

The project attached great importance to the capacity building of African researchers and technicians in terms of a visiting scholar program, training sessions and workshops.

A visiting scholar program was set up on the platform of the project that aimed to conduct cooperative theoretical and applied research with focus on various aspects of dryland agriculture. Two visiting scholars from Morocco, four from Zambia and four from Niger worked and studied in different Chinese institutions in phases I and II of the project (Fig. 6). The visiting scholars worked closely with Chinese researchers in the experimental and demonstration sites during their stay to learn about Chinese drought adaptation technology. The visiting scholars also visited
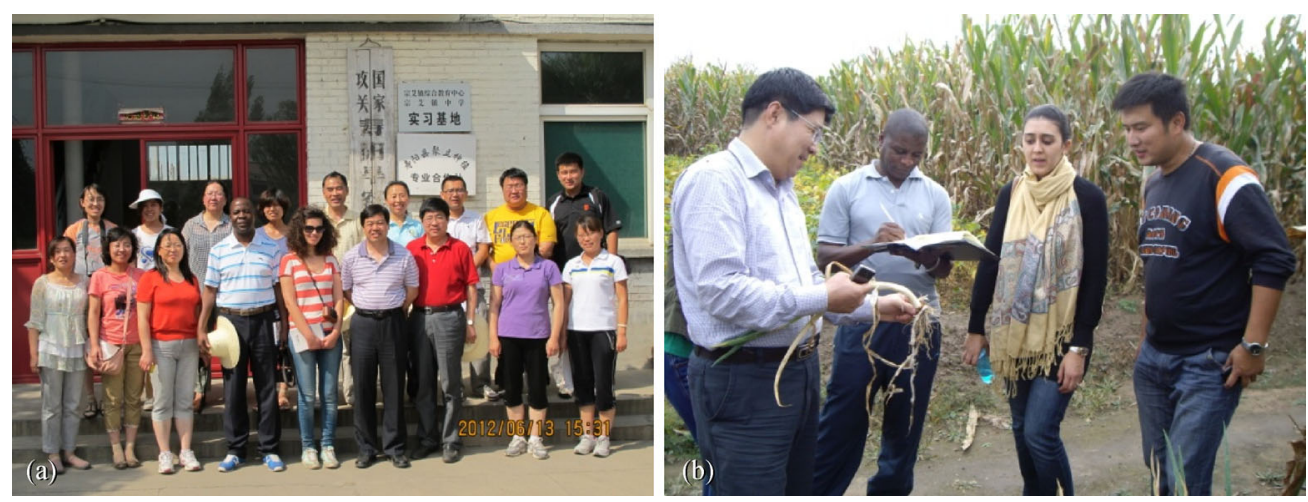

Fig. 6 Ten African visiting scholars were supported by the project. (a) June 13, 2012; 15:31 P.M.; (b) September 18, 2013; 10:43 A.M. 
key laboratories for water conservation farming, desert control and climate research, and communicated with Chinese scientists and technicians.

A series of training sessions on dryland agriculture and water conservation farming were given to African trainees at various locations in China (Fig. $7(a, b)$ ) and Africa (Fig. 7 (c,d)).The training sessions supported by the project are listed in Table 5. These training sessions lasted from one to 4 weeks. The trainees attended seminars and handson training given by the professors from the Chinese partners and other universities including China Agricultural University and the University of Melbourne, Australia. Eventually more than 200 researchers, 120 technicians and 350 farmers from Morocco, Zambia, Niger, Egypt and Ethiopia were trained. In addition, 10 Chinese postgraduates, 6 Moroccan postgraduates and 3 Moroccan undergraduates were trained in the project and awarded their degrees. The training programs worked as effective platforms for technology transfer and capacity building of African countries and also as bridges for cultural communication and mutual understanding.

\subsection{International meetings and symposia}

International meetings and symposia are a good way to summarize and exchange the expertise acquired and to discuss the experience and problems arising during the implementation of the project. They are also meaningful in enhancing the friendship between China and Africa, to further apply and extend the outcomes of the project, and to provide suggestions for the future development of the project.

Specifically, a field day and workshop of the Africa Water Action Project between China and United Nations organized by SAAS-IAER and INRA-SETTAT was held in Safi, Morocco on April 8-12, 2013 (Fig. 8 (a,b)). More than 90 participants who were leaders, technicians and local farmers from China, the United States, Zambia, Niger, Egypt, Ethiopia, Morocco, and the International Plant Nutrition Institute, attended the event. Thanks to the event, Chinese dryland farming and water conservation technologies were extended and applied in demonstration areas of North Africa, which works as a reference for the sustainable development of African agriculture and the extension of drought early warning systems and adaptation technology in other countries.

The Symposium on Drought Early Warning Systems and Adaptation Technology Cooperation between China and Africa organized by SAAS-IAER was held in Taiyuan, China from August 26 to September 23, 2013 (Fig. 8 (c,d)). Nine experts from INRA-SETTAT, Zambia Meteorological Department (ZMD), the University of Khemis Mialana, Algeria and more than 40 leaders and technicians from SAAS, Shanxi Department of Science and Technology, Lanzou University, Northwest A\&F University, and Gansu Desert Control Research Institute attended the symposium and exchanged their expertise and experience on DEWS and dryland farming under climate change. On August
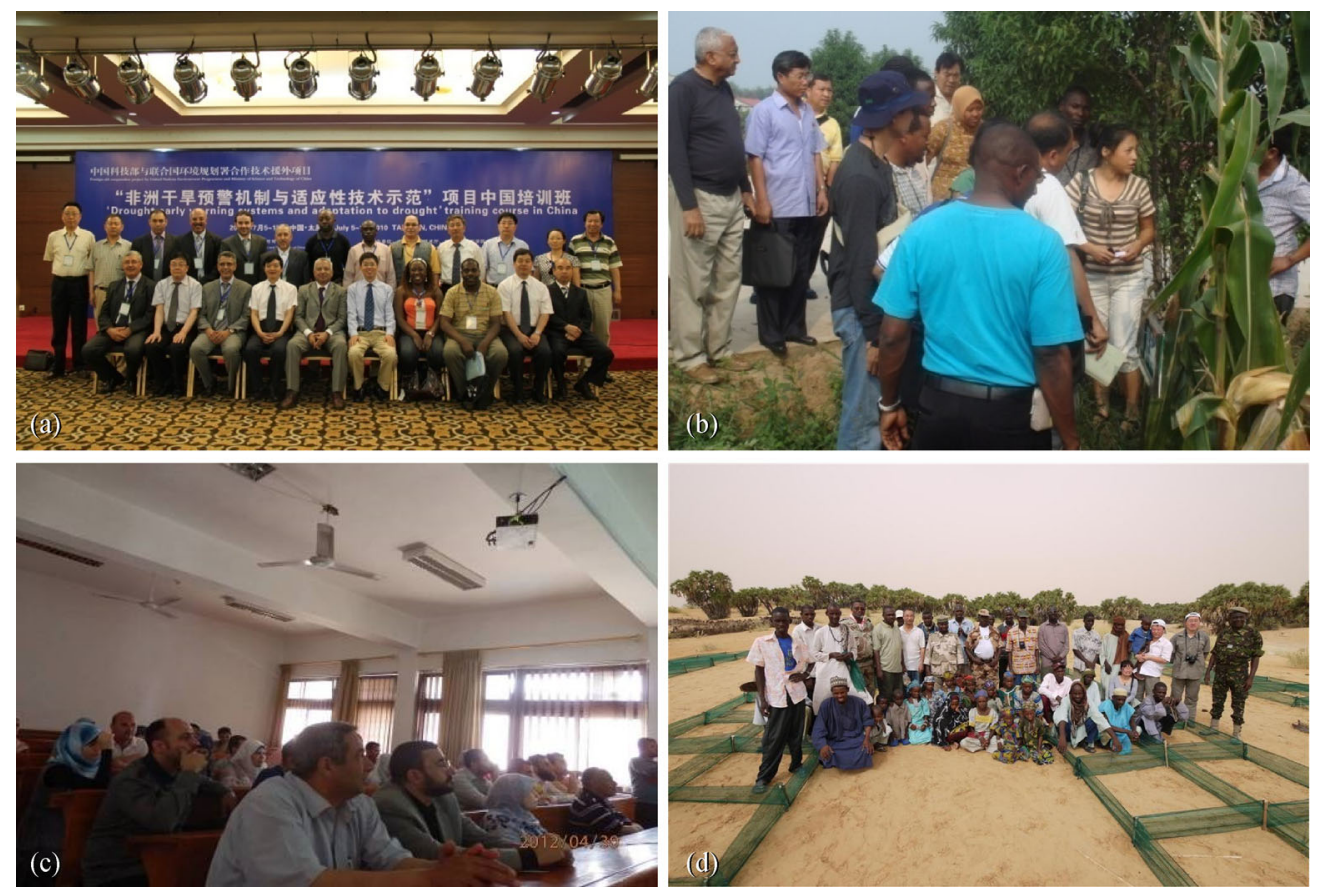

Fig. 7 The training sessions given in China and Africa served as effective platforms for technology transfer and capacity building on dryland agriculture. (a) Taiyuan, China (July 5, 2010; 10:52 A.M.); (b) Yangling, China (CYongzhong Feng \& Youzhen Xiang; August 28, 2011; 9:35 A.M.); (c) Ismailia, Egypt (CYongzhong Feng \& Youzhen Xiang; April 30, 2012; 11:28 A.M.); (d) Grouré, Niger (CFaming Li; June 10, 2012; 17:03 P.M.) 
26-30, 2013, the African experts visited the College of Environmental Science and Engineering, Tongji University, and a dryland irrigation facility producer for investigation and discussion of personnel exchange and sub-film drip irrigation technology.

\subsection{Publicity}

\subsubsection{Foreign activities}

The understanding and support from the local governments of African countries are important to technology acceptance, transfer and extension. Introduced by Moroccan project officer Dr. El Mzouri, project team members from SAAS-IAER visited the office of Dr. Mustafa, the Director of Agricultural Administration of Safi Province, Morocco, in October 2012 (Fig. 9 (a)). Dr. Mustafa was in charge of agricultural research and development of Safi and Youssoufia areas. Both parties exchanged ideas on crop management, agricultural production, and rural development. Dr. Mustafa expressed his interest in further cooperation in areas of agricultural research and extension, Green Morocco Plan and farmer schools. He also welcomed all types of queries and requests of assistance. A project team from SAAS-IAER paid a courtesy call on the Permanent Secretary (PS) of Southern Province, Dr. Mulenga, during a visit to the Zambia Meteorological Department (ZMD), Ministry of Transport, Works, Supply and Communications, Zambia in November 2012 (Fig. 9 (b)). The PS expressed positive comments on the project. He commented that cooperation between research institutions from Zambia and China would help develop both agriculture and also other areas of the Zambian economy. The PS also welcomed all types of queries and requests of assistance. The meetings with the African government officials exposed them to DEWS and drought adaptation technology and were an effective means of project publicity in Africa.

\subsubsection{Media coverage}

The Project has attracted extensive attention from and been reported by many media including China Daily, China News Channel, CHINAFRICA, UNEP IN CHINA, China Science Daily, Shanxi Daily, Shanxi Farmers Daily, and Gansu Daily. The media reports are helpful in expanding the influence of the project and attracting more cooperators. The Project also earned positive comments and ardent praise from our African partners.

\section{Conclusions and recommendations}

In general, the project was implemented smoothly and closed successfully with noticeable outcomes in terms of scientific reports, technical manuals, publications, patents and software copyrights, the DEWS platform and demonstration site construction, academic conferences, and training of African visiting scholars, technicians, farmers, postgraduates and undergraduates. Through the implementation of the project, selected technical problems in drought early warning and drought adaptation in typical dry areas in African countries were preliminarily resolved, adaptability of crops to drought enhanced, and sustainable development of agriculture promoted. Breakthroughs and innovations were achieved in the areas of drought forecasting based on remote sensing data, anti-drought technological system integration and application, and crop adaptability to drought in arid regions. The objectives of the project were accomplished successfully. The Chinese participants also developed a significant network of collaboration with UNEP and the African partners upon the finalization of the project.

The project teams met challenges and obtained valuable experience in their work in Africa, which may serve as reference for future work.

The volatile political situation and civil unrest in parts of Africa have been the largest constraint to the smooth implementation of the project, especially personnel and academic communication. In Egypt, for example, the outbreak of the Arab Spring in 2011 greatly influenced the exchange of personnel and restrained project progress in the country. In view of this, the political situation needs to be taken into account during the planning and implementation of a project.

In the application of Chinese agricultural technology, it is important to take the actual situation of different African countries into account. Some African partners are very conservative toward the introduction of new technologies and cultivars. For example, Egyptian researchers show great prudence to the introduction of drought-resistant coarse grains from China. We should therefore highly respect the opinions of the African cooperators and guarantee the biological and environmental safety of the exported technologies and cultivars. Chinese standards on the related technologies and products should also be enacted and observed.

The construction of the database and DEWS and the zoning work require a large amount of basic data. However, data deficiency was a common challenge for the project teams. In many cases the basic data needed to be gathered and sorted anew. More resources including funding and manpower should therefore be channeled to the data collecting system in the future as an enriched databank will facilitate the implementation of other tasks in the project.

The African partners were generally more interested in the assistance in terms of cutting-edge scientific equipment and medium- and small-sized agricultural machinery, as well as inviting African personnel to China for academic visits and training. In a project characterized by technology 
Table 5 Training sessions provided in China and Africa

\begin{tabular}{|c|c|c|c|c|}
\hline Date & Training content & Trainers & Trainees & Location \\
\hline July 2010 & $\begin{array}{l}\text { Demonstration of drought early } \\
\text { warning and adaptation } \\
\text { technology }\end{array}$ & $\begin{array}{l}\text { SAAS-IAER, China Agricul- } \\
\text { tural University and the Uni- } \\
\text { versity of Melbourne }\end{array}$ & $\begin{array}{l}19 \text { trainees from UNEP, } \\
\text { Morocco, Zambia, Libya, } \\
\text { and Egypt }\end{array}$ & Taiyuan, China \\
\hline August to September 2011 & $\begin{array}{l}\text { Demonstration and extension } \\
\text { systems of crop varieties, } \\
\text { production of seed potatoes and } \\
\text { seed production and propagation } \\
\text { technology of vegetables }\end{array}$ & Northwest A\&F University & $\begin{array}{l}45 \text { technicians and } 120 \\
\text { researchers from } 39 \\
\text { government departments and } \\
\text { agricultural universities of } 21 \\
\text { countries including Morocco, } \\
\text { Egypt, South Africa, Uganda, } \\
\text { and Sudan }\end{array}$ & Yangling, China \\
\hline September 2011 & $\begin{array}{l}\text { An Overview on Agricultural } \\
\text { Development in the Arid Area } \\
\text { of north-west China }\end{array}$ & Northwest A\&F University & $\begin{array}{l}24 \text { trainees from } 9 \text { countries } \\
\text { including Morocco and Egypt }\end{array}$ & Yangling, China \\
\hline April 2012 & $\begin{array}{l}\text { Experimentation, demonstration } \\
\text { and extension of Chinese dryland } \\
\text { drought adaptation technology }\end{array}$ & Northwest A\&F University & $\begin{array}{l}40 \text { professors and students } \\
\text { from the College of } \\
\text { Agricultural Engineering, the } \\
\text { College of Agriculture, and } \\
\text { the College of Resources and } \\
\text { Environment of Suez Canal } \\
\text { University }\end{array}$ & Ismailia, Egypt \\
\hline April 2013 & $\begin{array}{l}\text { Seed coating agent in production } \\
\text { of wheat and legumes, balanced } \\
\text { fertilization of wheat and legumes, } \\
\text { and zero-tillage, straw mulching } \\
\text { and nitrogen management of } \\
\text { wheat and legumes }\end{array}$ & $\begin{array}{l}\text { SAAS-IAER and INRA, } \\
\text { Morocco }\end{array}$ & $\begin{array}{l}20 \text { technicians, } 25 \text { students } \\
\text { and } 120 \text { local farmers }\end{array}$ & Safi, Morocco \\
\hline November 2012 & Dryland wheat cultivation & Northwest A\&F University & $\begin{array}{l}80 \text { farm owners, farm workers } \\
\text { and farmers }\end{array}$ & Ismailia, Egypt \\
\hline \multirow[t]{3}{*}{ June 2012} & Rain harvesting and reforestation. & $\begin{array}{l}\text { Gansu Desert Control } \\
\text { Research Institute }\end{array}$ & $\begin{array}{l}6 \text { local technicians and } 58 \\
\text { local farmers. }\end{array}$ & Niamey, Niger \\
\hline & $\begin{array}{l}\text { Sand dune fixation and } \\
\text { desertification control. }\end{array}$ & $\begin{array}{l}\text { Gansu Desert Control } \\
\text { Research Institute }\end{array}$ & $\begin{array}{l}20 \text { local technicians and } 60 \\
\text { local farmers. }\end{array}$ & Zinder, Niger \\
\hline & $\begin{array}{l}\text { Dryland maize and millet } \\
\text { cultivation }\end{array}$ & $\begin{array}{l}\text { Gansu Desert Control } \\
\text { Research Institute }\end{array}$ & $\begin{array}{l}4 \text { local technicians, } 30 \\
\text { members of the farmer } \\
\text { association and } 35 \text { local } \\
\text { farmers }\end{array}$ & Tava, Niger \\
\hline February 2014 & $\begin{array}{l}\text { Drought Early Warning } \\
\text { Workshop }\end{array}$ & $\begin{array}{l}\text { SAAS-IAER and Zambia } \\
\text { Meteorological Department }\end{array}$ & $\begin{array}{l}10 \text { technicians and } 3 \text { technical } \\
\text { specialists from Zambia } \\
\text { Meteorological Department } \\
\text { and the College of Agricultural } \\
\text { Sciences, the University of } \\
\text { Zambia }\end{array}$ & Choma, Zambia \\
\hline
\end{tabular}

transfer, however, the African partners need to pay more attention to the application of the transferred technologies and work as the main implementers in the lands of Africa to ensure continuing application and extension of the technologies after the withdrawal of the Chinese experts.

The transportation, communication and research facilities were underdeveloped in many areas of Africa. The researchers have to accept the fact and try best to make changes with African partners. Long-term prior planning, patient communication, and timely supervision according to the timeline are very important for the success of the project. Meanwhile, public spending on agricultural research and infrastructure in African countries needs to be increased. Furthermore, although interested by developed high-production technologies, the farmers in some areas of Africa still adhere to traditional farming patterns due to their traditional lifestyles and cultures, the scarcity of resources and the lack auxiliary facilities. It is therefore important for smallholder farmers to have access to updated agricultural information, small loans, certified seeds, inorganic fertilizers and affordable technologies. The establishment of regional value chains is crucial to connect farmers and markets. Being policy makers and implementers, the attitude of the officials of local 

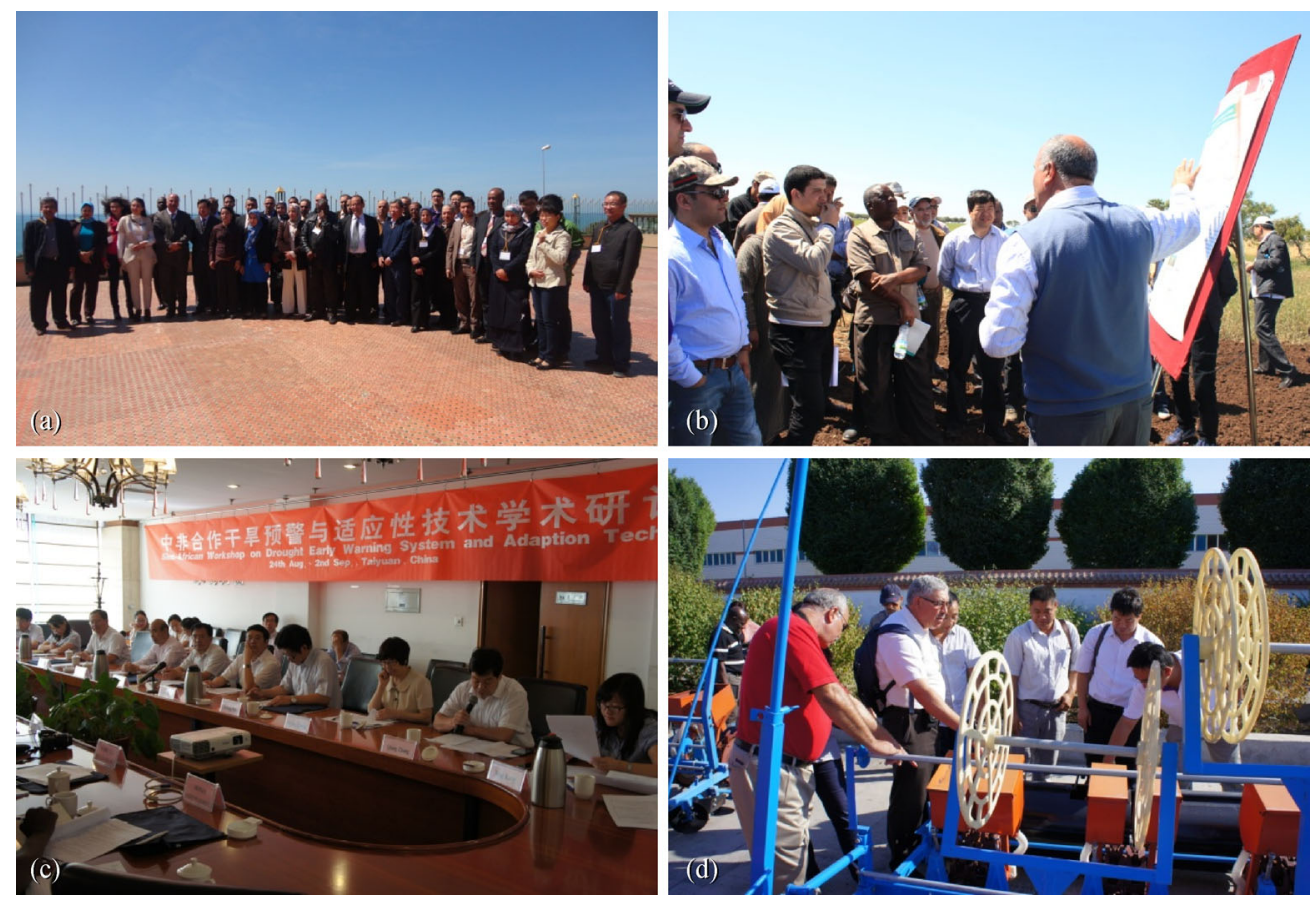

Fig. 8 The field day and workshop of the Africa Water Action Project held in Safi, Morocco ((a) April 9, 2013; 12:21 P.M.; (b) April 11, 2013; 11:43 A.M.) and the symposium on Drought Early Warning Systems and Adaptation Technology Cooperation held in Taiyuan, China ((c) September 1, 2013; 9:06 A.M.; (d) August 29, 2013; 17:25 P.M.).
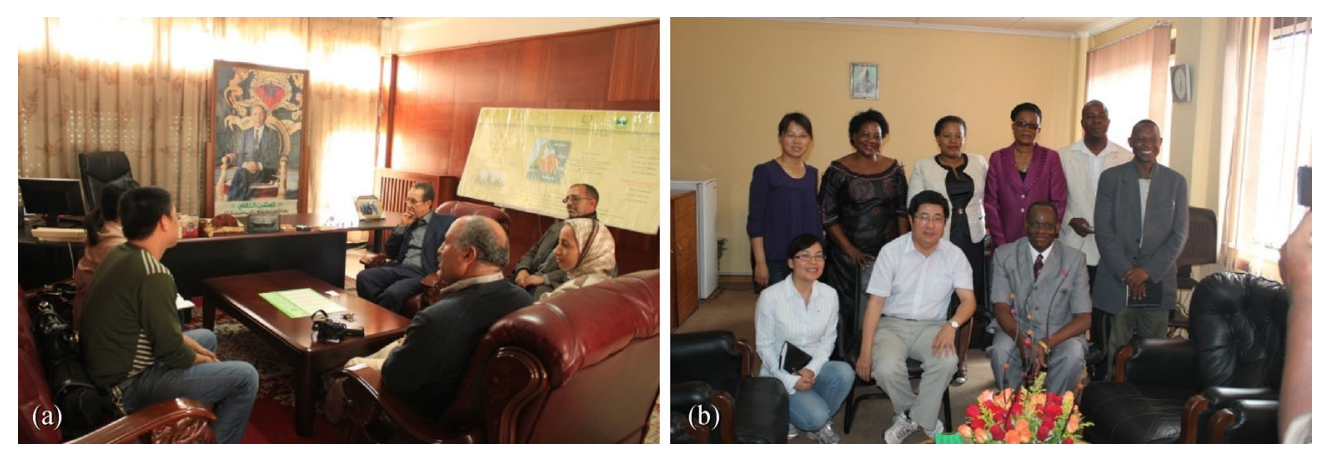

Fig. 9 Visits to African government officials promoted the publicity of the project. (a) Visit to Dr. Mustafa, the Director of Agriculture Administration of Safi Province, Morocco (October 30, 2012; 11:28 A.M.); (b) visit to Dr. Mulenga, the Permanent Secretary (PS) of Southern Province, Zambia (November 18, 2012; 10:26 A.M.).

governments and communities also matters. As suggested by Westermann ${ }^{[20]}$, more efforts need to be made in the scaling-up of the technologies by value chain development, private sector involvement, the use of information and communication technologies (ICTs) and associated agricultural advisory services, appropriate policies and political engagement once the technologies are proven to be transferable.

In the field investigations it was found that farm machinery made in the USA or Europe was designed primarily for large-scale commercial farms and is expensive, and therefore not suitable and affordable for smallholder farms and small farmers in Africa. By contrast, the African partners were very interested in medium- and small-sized farm machinery well popularized in China, which are competitively priced. However, Chinese farm machinery is not yet available in African markets. One of the Zambian visiting scholars even bought two Chinesemade tractors and replacements and had them shipped to his family farms at his own expense. There may therefore be a potentially large market for Chinese small farm machinery in Africa.

As we observed at the implementation of the project, African farmers and technicians are in the process of adapting to cope with climate change and food insecurity. Being a continent with high diversity of natural, 
agricultural and socio-economic conditions, Africa needs to identify and modify Chinese drought adaptation technologies carefully to meet the actual conditions indifferent countries or areas, and be resolute in implementation since agricultural development is a protracted tortuous process, as Chinese farmers have already experienced.

Acknowledgements We gratefully acknowledge funding from the Technological Assistance Program of MOST to Developing Countries (KY201904003), the International Cooperation Program of Shanxi Key R\&D Program (201903D421001), International Cooperation Program "Africa Water Action" between MOST and UNEP (2010DFA92860), Shanxi Key R\&D Program (201803D221011-1) and the S\&T Innovation Program of Shanxi Academy of Agricultural Sciences (YCX2018DZYX16).

Compliance with ethics guidelines Qiuxia Meng, Jianjie Zhang, Wenyan Xie, Huaiping Zhou, and Qiang Zhang declare that they have no conflicts of interest or financial conflicts to disclose.

This article does not contain any studies with human or animal subjects performed by any of the authors.

\section{References}

1. Chbouki N, Stockton C W, Myers D E. Spatio-temporal patterns of drought in Morocco. International Journal of Climatology, 1995, 15 (2): 187-205

2. Speth P, Christoph M, Diekkrüger B. Impacts of Global Change on the Hydrological Cycle in West and Northwest Africa. Heidelberg: Springer, 2010, 402-425

3. Voss R, May W, Roeckner E. Enhanced resolution modeling study on anthropogenic climate change: changes in extremes of the hydrological cycle. International Journal of Climatology, 2002, 22 (7): 755-777

4. Tebaldi C, Hayhoe K, Arblaster J M, Meehl G. Going to the extremes: an intercomparison of model-simulated historical and future changes in extreme events. Climatic Change, 2006, 79(3-4): 185-211

5. Intergovernmental Panel on Climate Change (IPCC). Climate Change, 2007: Synthesis Report. Contribution of Working Groups I, II and III to the Fourth Assessment Report of the Intergovernmental Panel on Climate Change. Geneva: IPCC, 2007, 50, 65

6. Intergovernmental Panel on Climate Change (IPCC). Climate change 2014: impacts, adaptation, and vulnerability. Cambridge: Cambridge University Press, 2014, 1199-1265
7. Schilling J, Freier K P, Hertig E, Scheffran J. Climate change, vulnerability and adaptation in North Africa with focus on Morocco. Agriculture, Ecosystems \& Environment, 2012, 156: 12-26

8. Yang D, Xiong W, Xu Y L. A review on impacts of climate change on water resource and agriculture in Africa. Chinese Journal of Agricultural Meteorology, 2016, 37(3): 259-269 (in Chinese)

9. Zhan S M. To meet climate change: the African stance and concerns. West Asia and Africa, 2009, (10): 42-49, 80 (in Chinese)

10. Food and Agriculture Organization of the United Nations (FAO). Trees, forests and land use in drylands: the first global assessment. Rome: FAO, 2019. Available at FAO website on May 15, 2020

11. The Economic and Social Commission for Western Asia (ESCWA), Economic and Social Council of United Nations. Report of the Regional Implementation Meeting of the Economic and Social Commission. New York: ESCWA, 2007, 15

12. Food and Agriculture Organization of the United Nations (FAO). FAOSTAT. Available at FAO website on May 13, 2020

13. Schlenker W, Lobell D B. Robust negative impacts of climate change on African agriculture. Environmental Research Letters, 2010, 5(1): 123-129

14. Thornton P K, Jones P G, Alagarswamy G, Andresen J, Herrero M. Adapting to climate change: agricultural system and household impacts in East Africa. Agricultural Systems, 2010, 103(2): 73-82

15. Cheru F, Modi R, Zhang D C. Catalyzing an agricultural revolution in Africa through South-South cooperation: the role of Chinese, Brazilian and Indian investments and knowledge exchange. International Social Science Journal, 2016, (4): 51-69 (in Chinese)

16. Li X F, Xu X G, Liu L Y. Land resources and their development in South America and Africa. Journal of Agricultural Science and Technology, 2008, 10(2): 56-66 (in Chinese)

17. Food and Agriculture Organization of the United Nations (FAO). Crop Prospects and Food Situation. Rome: FAO, 2013, 2-3. Available at FAO website on May 13, 2020

18. Food and Agriculture Organization of the United Nations (FAO). AQUASTAT-FAO's Global Information System on Water and Agriculture. Available at Food and AAO website on May14, 2020

19. Paeth H, Born K, Girmes R, Podzun R, Jacob D. Regional climate change in tropical and northern Africa due to greenhouse forcing and land use changes. Journal of Climate, 2009, 22(1): 114-132

20. Westermann O, Förch W, Thornton P, Körner J, Cramer L, Campbell B. Scaling up agricultural interventions: case studies of climate-smart agriculture. Agricultural Systems, 2018, 165: 283293 